\title{
Consumer Purchase Intentions Affected by Cause-Related-Marketing, Skepticism and Brand Loyalty: A Correlational Analysis
}

\author{
Fozia Rehmat ${ }^{1}$ \\ Student of MS Marketing at Institute of Business and Management University of \\ Engineering and Technology, Lahore Pakistan

\section{Tanzeela Farsam ${ }^{2}$} \\ Student of MS Marketing at Institute of Business and Management, University of \\ Engineering and Technology, Lahore Pakistan
}

\section{Muhammad Shabbir Ahmad ${ }^{3}$}

Student of MS at Institute of Business and Management University of Engineering and Technology, Lahore Pakistan

\section{Syyed Irfan Raza Naqvi ${ }^{4}$}

Student of MS Marketing at Institute of Business and Management University of Engineering and Technology, Lahore Pakistan

1 foziarehmat@hotmail.com

2 farsambashir@gmail.com

3 muhammadshabbirahmad@gmail.com

4 irfanrazanaqvi@gmail.com 


\begin{abstract}
:
Cause-Related-Marketing is an emerging strategy which is used to affect purchase intentions of a customer in a very positive way. Purchase intentions may braced by the brand loyalty which can be an outcome of the cause related efforts of marketing. But most of the companies ignore its impact towards skepticism. In this co-relational research, relationship between Cause Related Marketing and purchase intentions have been measured, whereas brand loyalty and skepticism played their role as intervening variables and their effect and nature of relationships are also being measured in this research. Data was gathered from different universities and organizations. Statistical analysis showed a positive relation between Cause Related Marketing, skepticism and brand loyalty. Further impact of both of these Intervening variables was administered on purchase intentions and it demonstrated that relationship between skepticism and purchase intentions was negative and very strong as compared to the positive correlation of brand loyalty and purchase intentions. Regression analysis also revealed very important information. In this research future research directions have also been discussed. This work is significant as achieved results can be helpful for the companies and theoretically it's important as this research filled a gap by studying the important variables together which have been subjects to much of discussion in Pakistan.
\end{abstract}

Keywords: Brand Loyalty, Cause Related Marketing, Philanthropy, Purchase Intentions, Skepticism, Social Responsibility 


\section{Introduction}

Pairing the altruistic causes with brands has emerged into a very prevalent practice among popular and well reputed brands from the last quarter of the nineteenth century. Usage of such pairing into the marketing communications is known as Cause-related marketing (Lafferty and Goldsmith, 2005). In Pakistan most of the known and unknown brands are involved in such practices. Emergence of the concept of corporate social activities among our domestic as well as international brands is a positive sign. These activities signal towards the betterment of a society if companies fulfil their claims. Recently a very well-known and established milk brand Olper's a brand of Engro foods limited started its campaign to help the needy women of far off areas of Pakistan. Among consumers this brand got much of appreciation and acceptance as this issue really needs to be supported by the strong entities of our country, but the fact is that companies always have their specific motives behind these activities ( and Cohen, 2008). Many other brands also have indulged themselves in the welfare campaigns. "Ufone" a known telecommunication network is participating to collect donations for making a new building of a known hospital "Shaukat Khanum Memorial Cancer Hospital and Research Centre" where cancer patients get free treatment. In late 1990s Ariel initiated a campaign "Help the Needy" during the month of Ramadan. As described by (Anghel et al 2011); message conveyed by influential personalities get much positive response. So Ariel used very influential celebrity to convey their message in a more convincing way to help the needy children by providing them education.

Customers are always interested to know that the brand they use is loyal to them and is not misguiding them at all. Questions regarding the fair usage of money keep on pinching the customer's thoughts and give birth to the hundreds of doubts. The fruition of cause-related marketing started from a historic article wrote by (Kotler and Levy, 1969) "Broadening the Concept of Marketing." They were of the view that conventional marketing should not have to be restricted to profit generating business; it can be stretched to the promotion of social issues and to support nonprofit organizations. This research has identified the peoples' consent about this strategy as it is very important to know that what others think about this technique. Rationale behind conducting this research is to scrutinize the positive and negative impact of cause related marketing which affects purchase intentions. Positive feelings are in a sense to generate brand loyalty which will finally lead people to buy a product and negative in a sense to generate doubts. Negative thoughts and doubts to question the reality of a campaign is known as skepticism (Anuar and Mohamad, 2012). Advertisements play their role in generating skepticism (Wang and Chien, 2012). Much of the national and international brands are using this strategy as it has become internationally recognized strategy (Kim and Choi, 2005). After analyzing the impact of cause related marketing on brand loyalty and skepticism 
their influence will be measured on purchase intentions to specify that to what extent different elements and practices can affect consumer purchase intentions.

\section{Literature Review}

Corporate social responsibility (CSR) in the form of corporate philanthropy has been practiced since as early as the late 1800s (Sethi, 1977). Corporate interest in social well-being began as deliberate responses to social issues, then evolved into a period of directive corporate concerns, and now evolving into a phase in which social conscientiousness is observed as an investment by companies (Stroup and Neubert, 1987). (Friedman 1970); believed that corporations should not be involved in political and social issues "The social responsibility of business is to increase its profits within the confines of the law". According to (Anghel, Grigore and Roșca 2009); companies are more fretful about the business partners and investors than the consumers and its employees and very few concerns are for the betterment of the society. It is known to be a kind of campaign through which company decides to donate a specific amount of their revenues on certain product or business in a mentioned time frame for the cause (Kotler and Lee, 2005). The notion of corporate social accountability and the technical way through which companies are using it in their marketing messages, is known as cause- related marketing (Bronn and Vrioni, 2000). Cause- Related Marketing is a marketing stratagem to increase profitability and to make contribution in monetary terms or otherwise to the nonprofit organization (Westberg 2004). There are a number of motives behind using the social initiative activities (Brønn and Cohen, 2008).It helps in gaining competitive advantage by increasing company reputation and it can build loyalty among customers (Papasolomou and Demetriou, 2005). It is fundamentally a marketing agenda that endeavor to realize two goals, one is to improve corporate performance and the other is to facilitate worthy causes (Varadarajan and Menon, 1988). Public understanding of charity is not clear, commercialization of a charitable/voluntary organization could put it in danger for the public approval and it may lead to the skepticism (Gurin, 1987). According to (Williams, 1986) one of the key rationales is that it is an approach for selling, not for producing liberal altruistic offerings. Skepticism is a cognitive component of attitudes, research sample of (Wang and Chien, 2012); were skeptical about advertisements of Cause-related marketing. From the previous studies it is proved that there are two basic motives, intrinsic and extrinsic motives. Extrinsic motives are perceived as egoistic or self-interested so these motives cause high level of skepticism (Cui, et al. 2003). (Bronn and Vrioni 2000); in United States a lot of companies are using Cause-related marketing that it lifts up the skepticism among people. Consumers often examine Cause Related Marketing as a utilization of a cause for a company's selfinterest (Forehand and Grier, 2003). Alone charitable intentions of an organization can no longer validate the altruistic giving and expenditures related to philanthropic actions in today's competitive marketplace (Bronn and Vrioni, 2000); and it signals the skepticism among 
consumer. Companies should consider their campaigns in order to reduce the level of consumer skepticism (Anuar and Mohamad, 2012). (Brink, Schröder and Pauwels 2006); discussed that this strategy causes a significant increase in brand loyalty. Research findings of (Babu and Mohiuddin, 2008) showed that customers influenced by the companies' cause related marketing programs and tended to be loyal with such companies. (Anghel, Florentina and Rosca, 2011) consumers prefer the products from the companies that are devoted to noble social causes whereas (Barone, Miyazaki and Taylor 2000) said that there is a little evidence to conform that customers are likely to choose the brands that are engaged in Cause-related marketing.

\section{Method and Material}

A research framework was developed to peruse this research work. In this model Cause Related Marketing was an independent variable and its effect on the purchase intentions was investigated. Skepticism and brand loyalty were considered as intervening/mediating variables and their influence on the purchase decision of consumers was measured after evaluating their relationship under the influence of Cause related marketing. Figure 1.2 below is showing the research framework.

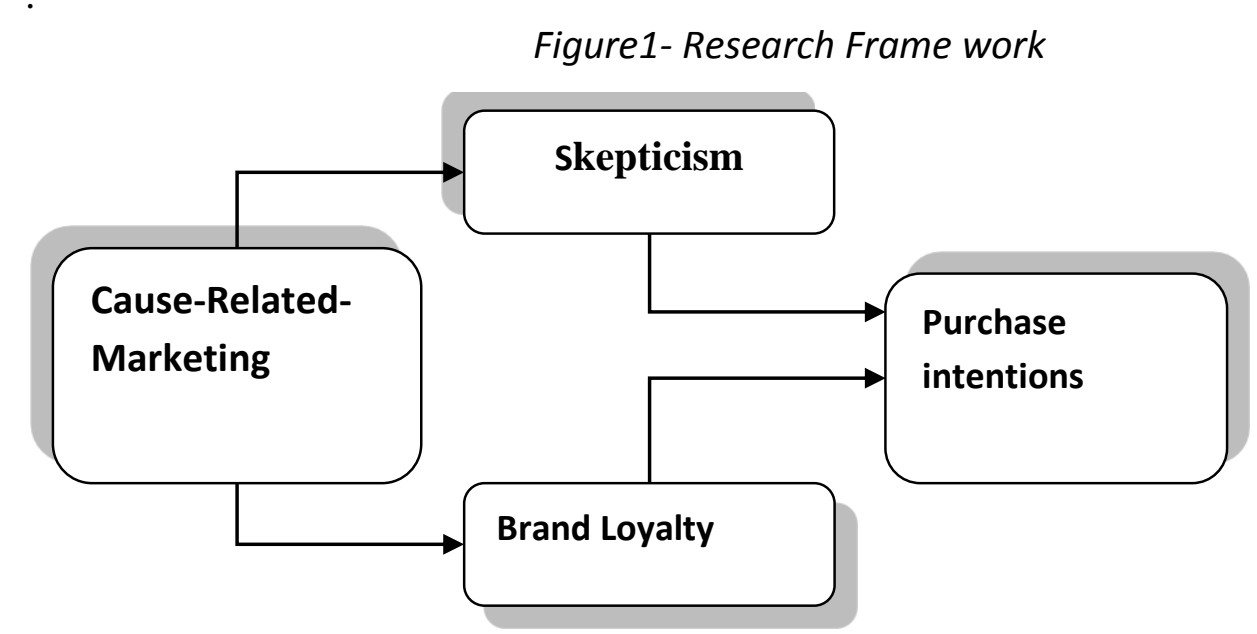

Few hypotheses have been crafted out for this research work Hypotheses for the Research:

- H1: There is a positive relationship between Skepticism and Cause-Related Marketing and has a significant influence on purchase intentions.

- H2: There is a negative relationship between Skepticism and Cause-Related Marketing and has a significant impact on purchase intentions.

- H3: There is a positive relationship between Brand loyalty and Cause-Related Marketing and has a significant impact on purchase intentions. 
- H4: There is a negative relationship between Brand loyalty and Cause-Related Marketing and has a significant impact on purchase intentions.

For achieving the best results from this research a non-probability sampling technique was used. Total 650 questionnaires were distributed to the different universities, offices, banks and private organizations. Only 570 filled questionnaires were collected back. After analyzing these responses, it was revealed that only 556 questionnaires were properly filled and these 556 responses were used for the statistical tests in SPSS. Thus it showed that total response rate was $85 \%$. It's depicting the sample size. Purposive sampling as a sub type of nonprobability sampling was used. It can be said that selection of the different places and people was done on the basis of the selective and subjective observation but no limitation was imposed on the bases of the age, gender, income level and education. Well-structured questionnaire consisting of 16 major items was administered as the data collection tool and in it 5 questions regarding the age, gender, education, occupation and selection of a cause from the given options were also included. Items for the questionnaire were adapted from the previous different researches. Four items related to the skepticism were used from the (Mohr et al, 1998) and other items were taken from (kim and Choi, 2005), (Anghel et al, 2011) and (Cui et al, 2003) for measuring the relation of Cause Related Marketing, brand loyalty and purchase intention, three items were adapted from the (Ellen et al, 2000) and (Stern \& Dietz, 1994). Few statements were used after a bit modification for the ease of the respondents. Responses were measured on the Likert scale. Demographics of the Research Sample: In the research sample, people belonging to different occupations were considered; students were also a part of this sample. In the sample of 556, there were 306 females that make a 55\% of the total sample. Male were, 250 in number which make the $45 \%$ of the sample. Majority of the sample, means $60.4 \%$ fall in the group of 26 to 30 years of age, in number they were 336 respondents. $20 \%$ of the sample was of the age of 20 to 25 years, whereas $16 \%$ of the sample belonged to the age group of 31 to 40 . Only 7 respondents were from the age group of 41 to 50 and only one respondent fall in the age group of 51 to 60 . No education limit was imposed while choosing the sample of the research. $43.9 \%$ of the sample had the education of 16 years it means that they were 244 out of total 556 respondents. $27.7 \%$ had 14 years of education which consist of 154 respondents. $16.5 \%$ respondents had 18 or more than 18 years of education it's depicting that sample was well-qualified which increases the accuracy rate of the research.

\section{Results}

Results of different statistical tests, were discussed in this section. All the gathered data was highly reliable and normal. First test was administered for checking reliability; value of 
cronbach's alpha was .854 which is very close to the ideal value. Values of $\alpha$ for the reliability of internal items scale are provided in the table below.

Table 4.1 Reliability Analysis (Per indicators)

\begin{tabular}{|l|l|l|}
\hline & No. of Items & Cronbach's alpha \\
\hline Cause-Related Marketing & 5 & .801 \\
\hline Skepticism & 5 & .909 \\
\hline Brand Loyalty & 6 & .871 \\
\hline Purchase Intentions & 5 & .867 \\
\hline
\end{tabular}

All these values can be considered highly reliable as values of Cause related marketing and brand loyalty are greater than 0.7 and lower than 0.9 According to the (Cortina, 1993) internal consistency is good if $0.7 \leq \alpha<0.9$ and excellent when $\alpha \geq 0.9$. Here all values could be known as reliable as all fall in the category of good excellent reliability values.

Analysis of Correlation: First correlation test was administered on three variables skepticism, brand loyalty and Cause Related Marketing. Here two variables were intervening variables, but in casual terms were considered as dependent on Cause related marketing. Results have been described in the table 4.3

Table 4.2 Correlation of CRM, Brand Loyalty and Skepticism

\begin{tabular}{|l|l|l|l|l|}
\hline & & Skepticism & $\begin{array}{l}\text { Brand- } \\
\text { Loyalty }\end{array}$ & $\begin{array}{l}\text { Cause-Related } \\
\text { Marketing }\end{array}$ \\
\hline Skepticism & $\begin{array}{l}\text { Pearson } \\
\text { Correlation }\end{array}$ & 1 & & \\
\cline { 2 - 6 } & Sig. & & & \\
\cline { 2 - 6 } & N & 556 & & \\
\hline Brand-Loyalty & $\begin{array}{l}\text { Pearson } \\
\text { Correlation }\end{array}$ & $-.180^{* *}$ & 1 & \\
\hline
\end{tabular}




\begin{tabular}{|l|l|l|l|l|}
\hline \multirow{2}{*}{} & Sig. & .000 & & \\
\cline { 2 - 5 } & $\mathrm{N}$ & 556 & 556 & \\
\hline $\begin{array}{l}\text { Cause-Related- } \\
\text { Marketing }\end{array}$ & $\begin{array}{l}\text { Pearson } \\
\text { Correlation }\end{array}$ & $.280^{* *}$ & $.737^{* *}$ & 1 \\
\cline { 2 - 5 } & Sig. & .000 & .000 & \\
\cline { 2 - 5 } & $\mathrm{N}$ & 556 & 556 & 556 \\
\hline
\end{tabular}

In this test it has been proved that these variables are positively correlated to each other. Level of significance of this relation is .000 which showed that the relation was highly significant $\mathrm{p}<.01$ and value of Pearson Correlation between Cause related marketing and skepticism is $\mathrm{r}$ $=.280$. This value is not very close to +1 but is very positive. Its showing that with the increase in CRM, level of Skepticism will also increase. Relationship between the CRM and brand loyalty was significant as $\mathrm{p}<.01$, value of Pearson correlation $r=.737$ which was positive and strong as it was close to +1 . It has been proved that the increase or decrease in CRM will also bring increase or decrease in the brand loyalty. Effect on the purchase intentions due to the brand loyalty and skepticism was analyzed separately by applying the tests of correlation.

Skepticism and Purchase Intention: On the next step impact of these two intervening variables were administered on purchase intentions. Correlation between skepticism and Purchase Intentions has been discussed below.

Table 4.3 correlation of skepticism and Purchase Intention

\begin{tabular}{|l|c|l|}
\hline & Skepticism & Purchase Intentions \\
\hline Skepticism & 1 & $-.444 *$ \\
\hline Purchase Intentions & $-.444 * *$ & 1 \\
\hline \multirow{2}{|l|}{$* *$. Correlation is significant at the 0.01 level, $\mathrm{n}=556$} \\
\hline
\end{tabular}

Relationship between the Purchase Intention and skepticism was negative as $r=-.444$ which was also significant as $p=.000$ which is $p<.01$. It's showing that when skepticism will increase purchase intentions will decrease and when skepticism will decrease its level then intentions for doing a purchase will increase. 
Brand Loyalty and Purchase Intention: Results of correlation among brand loyalty and purchase intentions are given below.

Table 4.4 correlation of Brand loyalty and Purchase Intention

\begin{tabular}{|c|c|c|}
\hline & Brand Loyalty & Purchase Intentions \\
\hline Brand Loyalty & 1 & $.237^{* *}$ \\
\hline Purchase Intentions & $.237^{* *}$ & 1 \\
\hline \multicolumn{2}{|c|}{$* *$. Correlation is significant at the 0.01 level , $\mathrm{n}=556$} \\
\hline
\end{tabular}

Relationship between the Purchase intentions and brand loyalty was also positive as Pearson correlation is $.237^{* *}$. But value was not too close to +1 so it's not a very weak relationship as compare to skepticism and purchase intention which was comparatively a very weak relation.

Results of Regression Analysis: Here values are given of two intervening variables that were brand loyalty and skepticism and independent variable as CRM.

Table 4.5- Regression Analysis

\begin{tabular}{|l|l|l|l|l|}
\hline & $\mathbf{R}$ & $\mathbf{R}^{2}$ & $\mathbf{F}$ & $\mathbf{P}$ \\
\hline Brand Loyalty & .737 & .544 & 659.685 & .000 \\
\hline Skepticism & .280 & .078 & 47.003 & .000 \\
\hline
\end{tabular}

For the goodness of the model, regression analysis had been used .Here the $\mathrm{R}=.737$ and its $\mathrm{R}^{2}=.544$ that is $54 \%$. Table is depicting that $54 \%$ variation in Brand Loyalty was due to the Cause related marketing. F value was 659.685 which showed that greater the possibility to use this prediction. It was also significant as $\mathrm{p}=.000$. So there are $0 \%$ chances to reject these outcomes. In the case of Skepticism $\mathrm{R}=.280$ which was low and $\mathrm{R}^{2}=.078$ it means that $07 \%$ variation in skepticism was due to Cause related marketing. Its showing that relation between these two variables was low as Cause Related Marketing had a very low role in generating skepticism. Value of F-test was 47.003 which are very significant as value was .000 . Result of regression analysis for skepticism and purchase intentions as dependent variable is given below. 
Table 4.6- Regression analysis for Skepticism and Purchase Intentions

\begin{tabular}{|c|c|c|c|c|}
\hline & $\mathbf{R}$ & $\mathbf{R}^{\mathbf{2}}$ & $\mathbf{F}$ & $\mathbf{P}$ \\
\hline Purchase Intention & -.444 & .197 & 135.954 & .000 \\
\hline
\end{tabular}

Its showing that how skepticism that was actually generated by CRM, will affect purchase intentions $\mathrm{R}=-.444$ its showing negative relation of these two variables whereas $\mathrm{R}^{2}=.197$ that is $19 \%$ variation in purchase intention was due to skepticism and it must be reminded that this relation was negative and $\mathrm{P}<.01$ so it's showing that values are significant.

Table below is presenting the results of purchase intentions affected by brand loyalty

Table 4.7 Regression analysis for Brand Loyalty and Purchase Intentions

\begin{tabular}{|l|l|l|l|l|}
\hline & $\mathbf{R}$ & $\mathbf{R}^{\mathbf{2}}$ & $\mathbf{F}$ & $\mathbf{P}$ \\
\hline Purchase Intention & .237 & .056 & 32.963 & .000 \\
\hline
\end{tabular}

This table is showing the extent to which brand loyalty instigated by CRM can affect purchase intentions. Value of $\mathrm{R}=.237$ and $\mathrm{R}^{2}=.056$ it means that only $05 \%$ variation in purchase intentions was due to Brand loyalty. It showed a clear picture that brand loyalty had a very poor role in building consumer purchase intentions. People show sympathies towards such campaigns but don't go for actual purchase. Equation by using the values of unstandardized coefficients can be used, first analysis presented the results obtained by assuming Cause related marketing as an independent variable and brand loyalty and skepticism as intervening dependent variables.

Skepticism $=b_{o}+b_{1} \mathrm{CRM} \rightarrow \quad 15.549+.288 \mathrm{CRM}$

$$
\begin{aligned}
& \mathbf{b}_{\mathbf{0}}=15.549 \text { it is significant as } \mathrm{t}(35.018), \mathrm{Sig}=.000, \mathrm{p}<.01 \\
& \mathbf{b}_{1}=0.288 \text { it is significant as } \mathrm{t}(6.856), \mathrm{Sig}=.000, \mathrm{p}<.01
\end{aligned}
$$

It's sowing that when there was no change in CRM, then skepticism value was 15.549 , but 1 unit change in CRM brought $28 \%$ change in skepticism.

Brand Loyalty $=b_{o}+b_{1} C R M \rightarrow 3.038+0.990 \mathrm{CRM}$

$$
\begin{aligned}
& \mathbf{b}_{\mathbf{0}}=3.038 \text { it is significant as t (7.467) Sig }=.000, p<.01 \\
& \mathbf{b}_{1}=0.990 \text { it is significant as t (25.684) Sig }=.000, p<.01
\end{aligned}
$$


This equation is showing that when there was no change in CRM then Brand Loyalty value was 3.038 but when there was 1 unit change in CRM it brought .990 change in Brand loyalty. So it's supporting that Cause Related Marketing is valuable for generating brand Loyalty. Now considering the next half of the research framework we examined the influence of two intervening variables "brand loyalty and skepticism" over dependent variable "Purchase Intentions".

Purchase Intentions $=b_{o}+b_{1} \operatorname{Skp}+b_{2} \mathrm{BL} \rightarrow 3.267+0.225 \mathrm{Skp}+0.055 \mathrm{BL}$

$$
\begin{aligned}
& \mathbf{b}_{\mathbf{0}}=3.267 \text { it is significant as } \mathrm{t}(8.097) \mathrm{Sig}=.000, \mathrm{p}<.01 \\
& \mathbf{b}_{1}=0.225 \text { it is significant as } \mathrm{t}(10.502) \mathrm{Sig}=.000, \mathrm{p}<.01 \\
& \mathbf{b}_{2}=0.055 \text { it is significant as } \mathrm{t}(3.357) \mathrm{Sig}=.001, \mathrm{p}<.01
\end{aligned}
$$

These values show that there were 3.26 values of purchase intentions when there was no change in independent variables. But when skepticism increased by 1 unit, it brought $22 \%$ variation in purchase intentions. So when Brand loyalty changed by 1 unit it caused only $05 \%$ change in purchase intentions.

\section{Discussion}

This section is to discuss the results achieved by this research. Here it can be argued that Cause-related -marketing has a strong positive relation with brand loyalty, and weak, but positive relation with skepticism as well. But results showed that both of these variables have different effects on the purchase intentions of consumers. As brand loyalty has the fragile ability to influence consumer purchase decisions, it definitely shows that sometimes positive attitude may not have great power to mold the decisions. Skepticism showed a strong influence upon the consumer purchase intentions. It has also been identified in literature as investigated by (Nedungad, 1990) and (Friel, 2004) that negative views and doubts can affect people's reactions. Results indicated that due to the increase in skepticism, consumer's intentions will decrease. Further discussion is done in terms of acceptance and rejection of the research hypothesis. It can be discussed that through this research the basic purpose or the objectives have been achieved by identifying the relationship between all the mentioned variables. It can be argued in terms of final status of our hypothesis, whereas four out of six hypotheses were accepted. Detailed discussion of each hypothesis is given in this section. H1 "There is a positive relationship between Skepticism and Cause-Related Marketing and has a significant influence on purchase intentions" results of correlation supported this hypothesis as $(\mathrm{r}=.280)$ it's highly significant because $\mathrm{p}<.01$ that is $(\mathrm{p}=.000)$. So to consider this result seriously, evidence can be taken from literature as in different continents CRM has been used enough by the brands that it laid the seeds of skepticism and had circled people with uncertainties 
(Bronn and Vrioni, 2000). Correlation between skepticism and purchase intentions is ( $\mathrm{r}=$ .444) it's negatively and strongly affecting the purchase intentions. It depicted that with the increase of skepticism (due to cause related marketing) will also affect the purchase intentions of the customers and decrease it. It is a disturbing situation as element of skepticism is a threat for the businesses as it also had a positive relation with CRM but weak as compare to brand loyalty as ( $\mathrm{r}=.280)$ yet its presence is very much disturbing as it negatively and strongly affect the purchase intentions as $(\mathrm{r}=-.444)$. (Forehand and Grier, 2003) showed their concerns that people take company's support to causes with doubts, so the same has been proved by the results of this research.

Hypothesis H2 " There is a negative relationship between Skepticism and Cause-Related Marketing and has a significant impact on purchase intentions" was not supported by the results of statistical techniques so it cannot be considered for the effectiveness of this research. Need of next hypotheses was felt due to the fact mentioned by (Westberg, 2004) that academic and practitioner research have shown strong consumer support for this concept but there is a limited evidence till the date regarding the effectiveness of this strategy in terms of purchase while comparing it with other strategies. $\mathrm{H} 3$ was about brand loyalty that "There is a positive relationship between Brand loyalty and Cause-Related Marketing and has a significant impact on purchase intentions" and it had been proved by the results as ( $\mathrm{r}=.737)$ its depicting that relationship is very strong and positive as well as $\mathrm{P}$ values also help to consider this hypothesis true as $\mathrm{p}<.01$ that is .000 . Past researches showed that to build a strong and positive image, a company needs a lot of efforts in terms of time and energy. In return, these efforts give enough fruit back to the company in terms of "Loyalty" by giving a sturdy prologue to the new products. To build demand for new and existing product lines it brings a great boost (Markwick and Fill, 1997). Second half of the hypothesis can be discussed by the results as indicated that there exists a very positive and a strong relation ( $r=.737)$ among the CRM and brand loyalty but this loyalty has further positive but weak relation with the purchase decision $(r=.237)$ and all these results are significant as for all values $\mathrm{p}<.01$ as $\mathrm{p}=.000$. So it is showing that there are less than .01 chances to reject these results. Results of this hypothesis brought major twist in this research. On the bases of the results $\mathrm{H} 4$ can be rejected.

From this study it can be said that this happens due to the fact that may be there is something wrong that stops consumers to go for a product even when there were positive feelings for a company. May be type of cause, type of message and message source are the few things that not helping the customers to fulfill their loyalty towards the companies in terms of purchasing. 


\section{Limitation and Conclusion}

Cause Related Marketing is a marketing strategy that can help the companies to generate loyalty among customers but small element of skepticism has much power to stop the customers from purchasing the products of that companies. Results of this research can be used in future researches to identify the influence of advance factors. Data and results are very helpful for the companies to indicate that only by adopting this strategy cannot produce the desired results; in addition to this technique company should have to focus on different aspects that can influence consumer. Many other factors also have strong impact on consumer purchase intentions which can even affect loyalty. This research can open ways to identify the influence of some other important variables on purchase intentions such as brand image, past experience, skepticism, company history, brand presence in relation to the brand loyalty and skepticism. Limitation has been imposed by the fact that it was not possible to collect data of specific companies and similarly it was not possible to describe the relationship of skepticism and brand loyalty with demographics and psychographics in this research due to the type of objectives and research limitation.

Finally it can be said that Cause-Related Marketing is an excellent way for the companies to boost their image and to get fame along with the betterment of a community where it operates (Westberg, 2004), so it should not be ignored or underestimate. The only thing that matters a lot is the way of implementation of such strategies, which should always be according to the ethical and legal values. 


\section{References}

Anghel L, D., Grigore G, F., \& Roşca M. (2009). Cause-Related Marketing, Part of Corporate Social Responsibility and Its Influence upon Consumers' Attitude. Amfiteatru Economic. 13(29)72-85.

Anuar, M. M., \& Mohamad, O. (2012). Effects of Skepticism on Consumer Response toward Cause-related Marketing in Malaysia. International Business Research, 5(9)12-38.

Babu, M. M., \& Mohiuddin, M. (2008). Cause Related Marketing and Its Impact on the Purchasing Behavior of the Customers of Bangladesh: An Empirical Study. AIUB Bus Econ Working Paper, Series No 2008-05. Retrieved from http://orp.aiub.edu/WorkingPaper/WorkingPaper.aspx?year=2008

Barone, M. J., Miyazaki, A. D., \& Taylor, K. A. (2000). The influence of cause-related marketing on consumer choice: Does one good turn deserve another? Journal of the Academy of Marketing Science, 28(2), 248-262.

Boush, D. M., Friestad, M., \& Rose, G. M. (1994). Adolescent skepticism toward TV advertising and knowledge of advertiser tactics. Journal of Consumer Research, 21(1), 165175.

Brink, D. V. D., Schröder,G.O., \& Pauwels,P. (2006). "The effect of strategic and tactical cause-related marketing on consumers' brand loyalty", Emerald 23.

Brønn, P. S., \& Cohen, D. V. (2008), Corporate Motives For Social Initiative: Legitimacy, Sustainability Or The Bottom Line?.Journal of Business Ethics.

Brønn, P. S., \& Vrioni,A. B. (2000). Measuring Skepticism to Cause Related Marketing: Preliminary Norwegian Results. Norwegian School of Management BI Department of Marketing, Discussion Paper.

Business in the Community (1998). Corporate survey report. Business in the Community, London.

Dennis, C., \& Smith, T. K. (1992), “Consumers Keen on Green but Marketers Don't Deliver," Advertising Age, 63 (29), 2-4. 
Cui, Y., Trent, E. S., Sullivan, P. M., \& Matiru, G. N. (2003). Cause-Related Marketing: How generation Y Responds. International Journal of Retail \& Distribution Management, 31(6), 310-320.

Ellen, P. S., Mohr, L. A., \& Webb, D. J. (2000). Charitable programs and the retailer: Do they mix?. Journal of Retailing, 76(3), 393-406. Retrieved from http://dx.doi.org/10.1016/S0022$\underline{4359(00) 00032-4}$

Forehand, M. R., \& Grier, S. (2003). When is honesty the best policy? The effect of stated company intent on consumer skepticism. Journal of Consumer Psychology, 349-356.

Friedman, M. (Sept. 13, 1970). The social responsibility of business is to increase its profits. The New York Times Magazine.

Goldman, R. (1996). Sign wars: The cluttered landscape of advertising. New York: Guildford Press.

Gurin, M. G. (1987), Cause-Related Marketing in Question. Advertising Age (27), S-16.

Kim, Y., \& Choi, S. M. (2005). Antecedents of green purchase behavior: an examination of collectivism, environmental concern, and perceived consumer effectiveness. Advances in Consumer Research, 32, 592-599.

Kotler P., Keller K, L., Koshy A., \& Jha M. (2009). Marketing Management, $13^{\text {th }}$ edition published by Dorling Kindersley (India) Pvt. Ltd., licensees of Pearson Education.

Kotler, P., \& Lee, N., 2005. Corporate social responsibility: doing the most good for your company and your cause. Hoboken: John Wiley.

Kotler, P., \& Levy, S. L. (1969). Broadening the Concept of Marketing. Journal of Marketing, 33 (1), 10-15

Lafferty, B. A., \& Goldsmith, R. E. (2005). Cause--brand alliances: does the cause help the brand or does the brand help the cause? Journal of Business Research, 58(4), 423-429.

Mohr, L. A., Ellen, P. S., \& Eroğlu,D. (1998). The development and testing of a measure of skepticism toward environmental claims in marketers' communications. The Journal of Consumer Affairs, 32(1), 30-55

Papasolomou, L., \& Demetriou, M. (2005). Cause-Related Marketing (CRM): Branding Financial Service Organizations In Cyprus By Aligning CSR With Business Motivations. International Review on Public and Non Profit Marketing, 2(2), 70-86. 
Sethi, S. P. (1977) Advocacy Advertising and Large Corporations, Lexington Books, Lexington, $M A$.

Stern, P.C., \& Dietz, T. (1994). The value basis of environmental concern. Journal of Social Issues, 50(3), 65-84.

Stivers, R. (1994). The culture of cynicism: American morality in decline. Cambridge, Mass.: Blackwell.

Stroup, M. A., \& Neubert, R. L. (1987). The Evolution of Social Responsibility. Business Horizons, 30 (March-April), 22-4.

Varadarajan, P. R., \& Menon, A. (1988). Cause-Related Marketing: A Co alignment of Marketing Strategy and Corporate Philanthropy. Journal of Marketing, 52(3), 58-74.

Wang, C. C., \& Chien, H. Y. (2012). Believe or Skepticism? An Empirical Study on Individuals' Attitude to Blog Product Review. International Journal of Innovation, Management and Technology, 3(4), -

Westberg, K. J. (2004).The Impact of Cause Related Marketing on Consumer Attitude to the Brand and Purchase Intention: A Comparison with Sponsorship and Sales Promotion. PhD Thesis, School of Marketing, Griffith University.

Williams, M. J. (1986). How to Cash in on Do-Good Pitches. Fortune, 114 (9), 71-80. 